\title{
Insulin and apolipoprotein A-1/C-III gene polymorphisms relating to hypertriglyceridaemia and diabetes mellitus
}

\author{
N. I.Jowett, A. Rees, L. G. Williams, J.Stocks, M. A. Vella, G. A. Hitman, J. Katz and D. J. Galton \\ Medical Professorial Unit, St. Bartholomew's Hospital, London, UK
}

Summary. Two gene specific probes have been used to identify polymorphic DNA loci on chromosome 11 close to the insulin and apoprotein A-1 genes in a genetic analysis of hypertriglyceridaemic patients with and without co-existing diabetes. Of the 45 patients studied with both probes, 15 were diabetic of whom nine possessed class $3 / 3$ insulin polymorphism genotypes, compared with none in the non-diabetic group $(p<$ $0.001 ; \chi^{2}$ test). In contrast, an uncommon apolipoprotein A-1 polymorphism was found to be equally distributed in the diabetic and the non-diabetic patients. No co-segregation of these two particular genetic polymorphisms was found in either patient group. The differing associations of the two disease-related polymorphism genotypes in patients with hypertriglyceridaemia with or without co-existing diabetes may possibly reflect differing aetiologies of the hyperlipidaemia.

Key words: Insulin gene, apoprotein genes, hypertriglyceridaemia, diabetes.
Diabetes mellitus and hypertriglyceridaemia are both common metabolic disorders, often found in association [1]. Diabetes is thought to affect at least $2 \%$ of the British population [2] and hypertriglyceridaemia (defined as fasting serum triglycerides $>2.0 \mathrm{mmol} / 1$ ) has been found to affect more than $10 \%$ of male populations in England and Scotland [3, 4]. Both diabetes and hypertriglyceridaemia are heterogeneous disorders, and although familial clustering sometimes occurs, they do not seem to segregate according to simple Mendelian principles. It is possible therefore that the mode of inheritance is polygenic, with two or more genes predisposing to the disease.

The recent developments in recombinant DNA technology have provided methods for detecting altered nucleotide sequences in the human genome which are inherited, and may therefore be used as genetic markers. These variations in DNA sequence can be demonstrated by cleaving genomic DNA with restriction enzymes, hybridising with cloned gene probes, and detecting changes in length of gene-related fragments. Such changes are termed "restriction fragment length polymorphisms" and unlike classical genetic markers where the gene is expressed and the protein identified (as with the HLA antigens), these DNA polymorphisms may be found in any region of the genome regardless of whether or not they encode for a protein [5]. Such poly- morphic loci have been identified flanking both the human insulin gene $[6,7]$, and the apolipoprotein $A-1 / C$ III gene complex [8]. A polymorphic region of DNA is found 363 base pair upstream $\left(5^{\prime}\right)$ from the initiation codon of the insulin gene. This consists of 14 base pair tandemly repeated DNA sequences in either short (class 1) or long (class 3) stretches [9]. Restriction fragment length polymorphism analysis of this locus has demonstrated an increased prevalence of class 3 alleles in hypertriglyceridaemic patients with co-existing diabetes [10]. Similarly, a DNA polymorphism close to the apolipoprotein A-1 gene has been shown to segregate in subjects with WHO types IV and V hyperlipidaemia [8]. Subsequently, this polymorphism has been shown to be situated in the $3^{\prime}$ non-coding region of the apolipoprotein C-III gene which lies approximately 2.8 kilobases (Kb) downstream from the apoprotein A-1 gene [11].

The apolipoproteins and insulin play important roles in lipoprotein metabolism. Apolipoprotein A-1 is a major peptide of HDL, and apolipoprotein C-III is a major component of triglyceride-rich lipoproteins. Insulin, in addition to its central role in glucose metabolism also influences plasma triglyceride levels [12]. It has a modulating effect upon the activity of lipoprotein lipase in tissues and thus regulates the catabolism of triglyceride-rich lipoproteins. In patients with diabetes where there is insulin deficiency or insulin resistance, 
hypertriglyceridaemia may result as a consequence of low lipoprotein lipase activity [13]. The insulin gene and the apolipoprotein A-1 gene have both been localised to the chromosome $11[14,15]$ which raises the possibility of an association of these genetic polymorphisms in hypertriglyceridaemia. We have therefore studied a further group of hypertriglyceridaemic patients with or without accompanying diabetes to ascertain whether these disease-related gene polymorphisms co-segregate or can be used to discriminate between these two patient groups.

\section{Subjects and methods}

\section{Subjects}

Caucasoid subjects ( 38 males, 8 females) with hypertriglyceridaemia were selected serially from the Lipid Clinic at St. Bartholomew's Hospital. Clinical details are shown in Table 1 . This group was defined by mean pre-treatment serum triglyceride concentrations $>2 \mathrm{mmol} / \mathrm{l}$ in three separate fasting venous blood samples, and complete lipid analysis showed that the group comprised WHO classes IIb and IV/V in equal numbers. Glucose tolerance was assessed in all subjects using a standard $75 \mathrm{~g}$ oral glucose tolerance test as detailed in the WHO (1980) recommendations [16], and 45 patients were divided into diabetic $(n=15)$ and non-diabetic $(n=30)$ sub-groups. The remaining patient had impaired glucose tolerance and was dropped from the study. At the time of genotyping, hyperglycaemia was being treated in the diabetic patients by diet alone (7), oral hypoglycaemic agents (5) and insulin (3) although none were insulin-dependent - that is, there was no history of previous diabetic ketoacidosis. Despite adequate hypoglycaemic therapy, hypertriglyceridaemia had persisted requiring further dietary manipulation as well as treatment with hypolipidaemic drugs, including clofibrate and nicotinic acid.

\section{Methods}

DNA was isolated from peripheral leucocytes in $10 \mathrm{ml}$ venous blood essentially by the method of Kunkel et al. [17]. DNA samples were digested with restriction endonuclease Sst I according to the manufacturers, recommendations (Bethesda Research Laboratories, Cambridge, UK) and then Southern blotted as described elsewhere [6, 18]. The nitrocellulose filters were hybridised with either a ${ }^{32} \mathrm{P}$-labelled insulin gene or the apoprotein A-1 gene probe, and resulting hybrids were visualised by autoradiography.

\section{Statistical analysis}

The association of gene related polymorphisms with diabetes, hypertriglyceridaemia or both was analysed by a $3 \times 2$ contingency table comparing the polymorphism genotype with the disease group. A $\chi^{2}$ test of independence was then applied.

\section{Results}

\section{Genotyping of the polymorphisms}

Insulin gene polymorphism: Two major gene related fragments were identified: (1) $6.0 \pm 0.3 \mathrm{~Kb}$ (class 1 alleles); (2) $7.5 \pm 0.4 \mathrm{~Kb}$ (class 3 alleles). Patients were genotyped $1 / 1,1 / 3$ or $3 / 3$ for the DNA insertion within the polymorphic region.
Table 1. Clinical features of the study groups

\begin{tabular}{lccc}
\hline & \multicolumn{3}{l}{ Patients with hypertriglyceridaemia: } \\
\cline { 2 - 4 } & Total & $\begin{array}{c}\text { Type } 2 \\
\text { diabetic } \\
(n=15)\end{array}$ & Non-diabetic \\
& $(n=45)$ & $(n=30)$ \\
\hline Age at diagnosis (years) & $53.8 \pm 6.8$ & $54.2 \pm 8.3$ & $53.4 \pm 7.2$ \\
& $(30-67)$ & $(49-63)$ & $(30-67)$ \\
Sex: M:F & $37: 8$ & $10: 5$ & $27: 3$ \\
Fasting pre-treatment & $8.0 \pm 2.3$ & $8.5 \pm 2.5$ & $7.7 \pm 2.1$ \\
serum cholesterol & $(4.9-14.5)$ & $(4.9-14.5)$ & $(5.3-13.0)$ \\
(mmol/1) & & & \\
Triglycerides (mmol/1) & $6.2 \pm 4.8$ & $7.5 \pm 6.0$ & $5.5 \pm 4.2$ \\
& $(2.3-19.5)$ & $(2.6-19.5)$ & $(2.3-18.7)$ \\
Plasma glucose & $9.8 \pm 5.9$ & $15.1 \pm 3.3$ & $4.3 \pm 0.18$ \\
(mmol/1) & $(3.5-20.1)$ & $(10.9-20.1)$ & $(3.5-5.3)$ \\
Body mass index & $27.3 \pm 4.4$ & $26.6 \pm 4.8$ & $26.6 \pm 4.1$ \\
& $(21-44)$ & $(21-41)$ & $(21-39)$ \\
\hline
\end{tabular}

Results expressed as mean \pm SD with range in parentheses a calculated by weight $(\mathrm{kg}) \div$ height $\left(\mathrm{m}^{2}\right)$

Table 2. Polymorphism genotypes in hypertriglyceridaemic subjects with or without diabetes mellitus

\begin{tabular}{|c|c|c|c|c|c|}
\hline \multirow{3}{*}{$\begin{array}{l}\text { Patients with } \\
\text { hypertri- } \\
\text { glyceridaemia }\end{array}$} & \multicolumn{5}{|c|}{ Polymorphism genotype } \\
\hline & \multicolumn{3}{|c|}{ Insulin genotype } & \multicolumn{2}{|c|}{$\begin{array}{l}\text { Apoprotein A-I } \\
\text { genotype }\end{array}$} \\
\hline & $1 / 1$ & $1 / 3$ & $3 / 3$ & $\begin{array}{l}\text { Common } \\
\text { homo- } \\
\text { zygote }\end{array}$ & $\begin{array}{l}\text { Uncommon } \\
\text { hetero- } \\
\text { zygote }\end{array}$ \\
\hline $\begin{array}{l}\text { With diabetes } \\
(n=15)\end{array}$ & $\begin{array}{c}2 \\
(13 \%)\end{array}$ & $\begin{array}{c}4 \\
(27 \%)\end{array}$ & $\begin{array}{c}9 \\
(60 \%)\end{array}$ & $\begin{array}{l}10 \\
(67 \%)\end{array}$ & $\begin{array}{c}5 \\
(33 \%)\end{array}$ \\
\hline $\begin{array}{l}\text { WHO type IIb } \\
(n=8)\end{array}$ & 1 & 2 & 5 & 7 & 1 \\
\hline $\begin{array}{l}\text { WHO } \\
\text { type IV/V } \\
(n=7)\end{array}$ & 1 & 2 & 4 & 3 & 4 \\
\hline $\begin{array}{l}\text { Without diabetes } \\
(n=30)\end{array}$ & $\begin{array}{c}7 \\
(23 \%)\end{array}$ & $\begin{array}{l}23 \\
(77 \%)\end{array}$ & $\begin{array}{l}0 \\
(0 \%)\end{array}$ & $\begin{array}{l}20 \\
(67 \%)\end{array}$ & $\begin{array}{l}10 \\
(33 \%)\end{array}$ \\
\hline $\begin{array}{l}\text { WHO type IIb } \\
(n=14)\end{array}$ & 5 & 9 & 0 & 10 & 4 \\
\hline $\begin{array}{l}\text { WHO } \\
\text { type IV/V } \\
(n=16)\end{array}$ & 2 & 14 & 0 & 10 & 6 \\
\hline $\begin{array}{l}\text { Total } \\
(n=45)\end{array}$ & $\begin{array}{c}9 \\
(20 \%)\end{array}$ & $\begin{array}{l}27 \\
(60 \%)\end{array}$ & $\begin{array}{c}9 \\
(20 \%)\end{array}$ & $\begin{array}{l}30 \\
(67 \%)\end{array}$ & $\begin{array}{l}15 \\
(33 \%)\end{array}$ \\
\hline
\end{tabular}

$\chi^{2}$ analysis for comparison of insulin genotypes in diabetic and nondiabetic hypertriglyceridaemia using a $3 \times 2$ contingency table with two degrees of freedom gives a $\chi^{2}$ value of $22.67 ; p<0.001$. There is no difference in the distribution of apoprotein A-1 polymorphisms

Apolipoprotein A-1/C-III polymorphism: Three major gene related fragments were identified: $5.7,4.2$ and $3.2 \mathrm{~Kb}$ in two combinations: (1) $5.7 \mathrm{~Kb}, 4.2 \mathrm{~Kb}$ (common homozygote); (2) $5.7 \mathrm{~Kb}, 4.2 \mathrm{~Kb}, 3.2 \mathrm{~Kb}$ (uncommon heterozygote).

Of the 45 subjects with hypertriglyceridaemia studied, 15 were diabetic although none was insulin-dependent. Of this group, nine possessed the class $3 / 3$ genotype compared with none in the non-diabetic group 


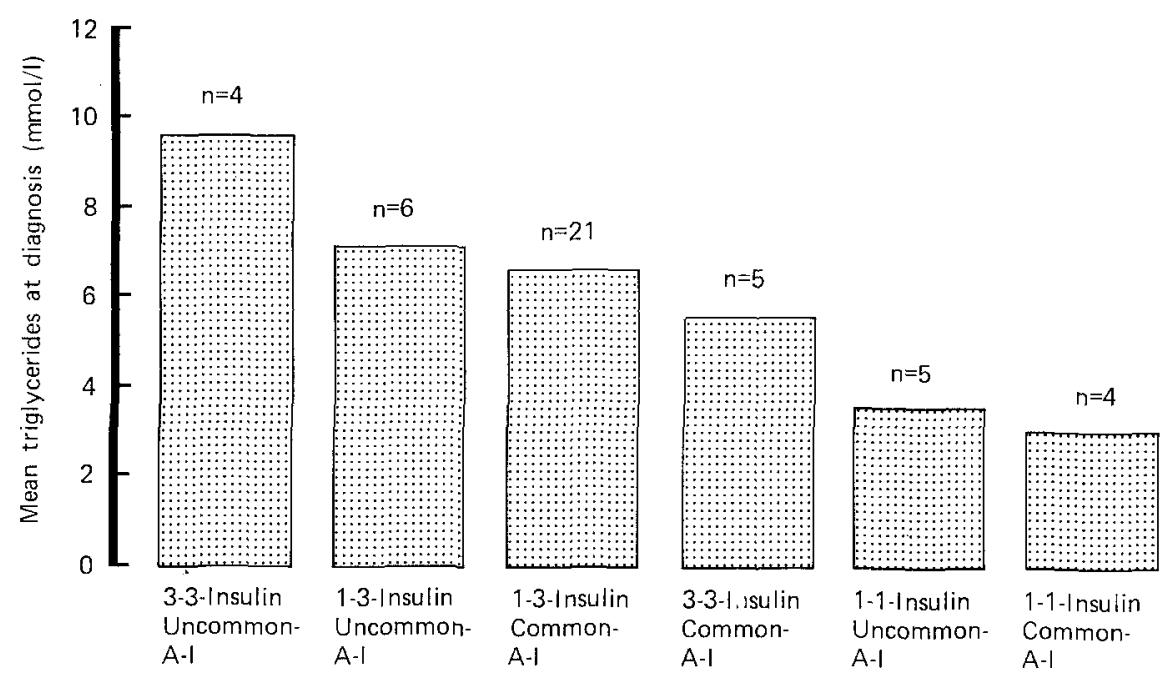

Fig. 1. Mean serum triglyceride levels before treatment in subjects with differing combinations of apoprotein A-1 and insulin polymorphism genotypes
(Table 2). This supports our previous findings [10] of preferential segregation of the homozygous class 3 genotype (3/3) with diabetic as opposed to non-diabetic hypertriglyceridaemia $\left(\chi^{2}=22.67 ; p<0.001\right)$. In contrast, however, the apoprotein A-1/C-III polymorphism, although found in increased prevalence in the hypertriglyceridaemic subjects, distributes equally between diabetic and non-diabetic patients. Furthermore, no significant co-segregation of the disease-related polymorphisms ( $3 / 3$ and uncommon heterozygotes) was found in either group. Only four patients possessed both of these rare genotypes, all of which were diabetic, and interestingly, the mean pre-treatment triglyceride level for this group was $9.6 \pm 6.5 \mathrm{mmol} / \mathrm{l}$. This contrasts with the milder lipid abnormalities found in other combinations of the polymorphisms (Fig.1). The severity of the lipaemia in this group cannot be explained on the basis of diabetes alone, as the average triglyceride levels at presentation for the remaining 11 diabetic patients was $6.7 \pm 5.2 \mathrm{mmol} / \mathrm{l}$. No difference in distribution of the DNA polymorphism was observed in WHO subtypes IIb, IV or V hyperlipoproteinaemia.

\section{Discussion}

The precise molecular and genetic defects in many common metabolic diseases, such as diabetes and hypertriglyceridaemia, are unknown. Using this new approach, restriction fragment length analysis, it is possible to identify polymorphic sequences which segregate with particular phenotypic features without knowing the identity of the predisposing gene or genes. It may thus be possible to identify common genetic determinants which form the inherited component of polygenic diseases. Previous work has shown an increased frequency of the uncommon $3 / 3$ insulin polymorphism genotype and the uncommon heterozygous apoprotein A-1 geno- type in patients with hypertriglyceridaemia compared to control subjects with normal fasting serum lipids [8, 10]. However, we now find that whereas the insulin gene polymorphism segregates in patients with hypertriglyceridaemia and diabetes, the apoprotein A-1/C-III polymorphism relates only to hypertriglyceridaemia and is not dependent upon glucose tolerance. In addition, despite both genes being on the same chromosome $[14,15]$ they do not appear to co-segregate in patients with hypertriglyceridaemia.

Patients with Type 2 (non-insulin-dependent) diabetes have a higher incidence of hypertriglyceridaemia than normal individuals [19]. Although there are many known factors relating to hypertriglyceridaemia secondary to glucose intolerance (e.g. obesity, high carbohydrate diet, low activity of lipoprotein lipase), the persistant elevation of triglyceride despite adequate hypoglycaemic therapy may be explained by a co-existing primary hyperlipoproteinaemia. Diabetes and primary hyperlipidaemia are common conditions and thus may occur together on the basis of chance alone [20]. It may be therefore that the DNA polymorphisms hitherto described segregate with hypertriglyceridaemia of differing aetiologies. The class $3 / 3$ insulin genotype may relate to the secondary hypertriglyceridaemia of diabetes mellitus, whereas the apoprotein A-1/C-III polymorphism may associate with primary hypertriglyceridaemia. In accordance with this hypothesis, it is seen that in the four individuals possessing both the disease-related polymorphisms ( $3 / 3$ insulin; uncommon apoprotein A-1), severe hypertriglyceridaemia is found which may reflect the expression of a primary and secondary hypertriglyceridaemia in the same patient. We are therefore carrying out further multiple gene probe analyses (including those of the other apolipoproteins) to establish other restriction fragment polymorphisms which may associate with hyperlipidaemic phenotypes, and thus identify common inherited components of these polygenic metabolic disorders. 
Acknowledgements. This work was supported by the British Diabetic Association, the Joint Research Board of St. Bartholomew's Hospital, London, UK, and the Fritz-Thysson Foundation, FRG.

The insulin gene probe was kindly provided by Dr. G. I. Bell of the University of California, USA, and the apoprotein A-1 gene probe by Dr. F. E. Baralle of the Dunn School of Pathology, Oxford.

\section{References}

1. Glueck CJ, Levy RI, Fredrickson DS (1969) Immunoreactive insulin, glucose tolerance, and carbohydrate inducibility in types II, III, IV and V hyperlipoproteinaemia. Diabetes 18: 739-747

2. Wadsworth MEJ, Jarrett RJ (1974) Incidence of diabetes in the first 26 years of life. Lancet 2: 1172-1174

3. Lewis B, Chait A, Wootton ID, Oakley CM, Krikler DM, Sigurdsson G, February A, Maurer B, Birkhead J (1974) Frequency of risk factors for ischaemic heart disease in a healthy British population with particular reference to serum lipoprotein levels. Lancet 1: 141-146

4. Lorimer AR, Cox FC, Greaves DA, Jubb JS, Hawthorne VM, Morgan HG, Lawrie TDW (1974) Prevalence of hyperlipoproteinaemia in apparent healthy man. Br Heart J 36: 192-196

5. Botstein D, White R, Skolnick M, Davis R (1980) Construction of a genetic linkage map in man using restriction fragment length polymorphisms. Ann Rev Genet 32: 314-331

6. Bell GI, Karam J, Rutter W (1981) A polymorphic DNA region adjacent to the $5^{\prime}$ end of the human insulin gene. Proc Natl Acad Sci USA 78: 5759-5763

7. Ullrich A, Dull TJ, Gray A, Philips JA, Peter S (1982) Variation in the sequence and modification state of the human insulin gene flanking regions. Nucleic Acids Res 10: 2225-2240

8. Rees A, Shoulders CC, Stocks J, Baralle FE, Galton DJ (1983) DNA polymorphism adjacent to the human apoprotein A-1 gene: relation to hypertriglyceridaemia. Lancet 2: 444-446

9. Bell GI, Selby M, Rutter W (1982) The highly polymorphic region near the insulin gene is composed of simple tandemly repeating sequences. Nature 295: 31-35

10. Jowett NI, Williams LG, Hitman GA, Galton DJ (1984) Diabetic hypertriglyceridaemia and related $5^{\prime}$ flanking polymorphism of the human insulin gene. $\mathrm{Br}$ Med J 288: 96-99
11. Karathanasis SK, Norum RA, Zannis VI, Breslow JL (1983) An inherited polymorphism in the human apolipoprotein A-1 gene locus related to the development of atherosclerosis. Nature 301: $718-720$

12. Pykalisto OJ, Smith PH, Brunzell JD (1975) Determinants of human adipose tissue lipoprotein lipase. J Clin Invest 56:1100-1117

13. Taylor KG, Galton DJ, Holdsworth G (1979) Insulin-independent diabetes: a defect in the activity of lipoprotein lipase in adipose tissue. Diabetologia 16:313-317

14. Owerbach D, Bell G, Rutter W, Brown J, Shows T (1981) The insulin gene located on the short arm of chromosome 11 in humans. Diabetes 30:267-270

15. Law SW, Gray G, Brewer HB, Sakaguchi AY, Naylor SL (1984) Human apolipoprotein A-1 and C-III genes reside in the p11-q13 region of chromosome 11. Biochem Biophys Res Commun 118: 934-942

16. WHO Expert Committee on Diabetes Mellitus (1980) Second report. WHO Technical Report Series No.646. Geneva

17. Kunkel LM, Smith KD, Boyer SH, Borgaonkar DS, Wachtel SS, Miller OJ, Breg WR, Jones HW, Rary JM (1977) Analysis of human $Y$ chromosome specific reiterated DNA in chromosome variants. Proc Natl Acad Sci USA 74: 1245-1249

18. Southern E (1979) Gel electrophoresis of restriction fragments. Methods Enzymol 68: 27-32

19. Santen RJ, Willis PW, Fajans SS (1972) Atherosclerosis in diabetes mellitus. Correlations with serum lipid levels, adiposity and serum insulin levels. Arch Intern Med 130: 833-843

20. Brunzell JD, Hazzard WR, Motulsky AG, Bierman EL (1975) Evidence for diabetes and genetic forms of hypertriglyceridaemia as independent entities. Metabolism 24: 1115-1121

Received: 12 January 1984

and in revised form: 7 May 1984

Dr. D. J.Galton

Department of Medicine

St. Bartholomew's Hospital

London EC1A 7BE

UK 